\title{
PREFERENSI SISWA SMA SURABAYA DALAM PENCARIAN INFORMASI STUDI LANJUT PERGURUAN TINGGI
}

\author{
Theresia Intan ${ }^{1 *}$, Brigitta Revia ${ }^{1}$ \\ ${ }^{1}$ Universitas Katolik Widya Mandala Surabaya \\ Email : theresiaintan2502@gmail.com
}

\begin{abstract}
ABSTRAK
Penelitian ingin mengetahui bagaimana preferensi Siswa SMA Surabaya dalam Pencarian Informasi Studi Lanjut Perguruan Tinggi. Pemilihan fokus penelitian mengenai siswa SMA di Surabaya dalam pencarian informasi studi lanjut perguruan tinggi. Metode yang digunakan adalah metode penelitian survey. Hasil penelitian ini, pada pencarian informasi menggunakan sumber personal, bahwa terkait topik kesesuaia njurusan yang akan dipilih Guru Bimbingan Konseling menjadi sumber informasi utama siswa SMA. Namun untuk penentuan Universitas mana yang akan dipilih, siswa SMA cenderung mencari informasi kepada orang tua. Pencarian informasi pada media publikasi yang berbeda-beda. Terlihat pada preferensi pilihan pertama pada kategori pilihan 1, media publikasi yang paling banyak digunakan adalah Instagram yang dimiliki oleh masing-masing perguruan tinggi. Kategori pilihan yang kedua, media publikasi yang paling banyak digunakan adalah facebook perguruan tinggi.
\end{abstract}

\section{Kata Kunci : Preferensi Media; Siswa SMA; Perguruan Tinggi}

\section{Submisi : 31 Maret 2019}

\section{Pendahuluan}

Penelitian ini bermaksud ingin mengetahui bagaimana preferensi Siswa SMA Surabaya dalam Pencarian Informasi Studi Lanjut Perguruan Tinggi. Pemilihan fokus penelitian mengenai siswa SMA di Surabaya dalam pencarian informasi studi lanjut perguruan tinggi. Hal tersebut berlandaskan fenomena banyaknya muncul media baru untuk pencarian informasi yang beredar di sekitar remaja sekarang ini khususnya siswa SMA di Surabaya dan banyaknya kemunculan perguruan tinggi baru yang gencar mencari mahasiswa untuk mengemban pendidikan tinggi. Remaja Surabaya,merupakan audience aktif yang memiliki kebebasan dalam menggunakan dan memilih media informasi untuk memenuhi kebutuhan akan informasi. Teori utama dalam penelitian ini adalah Uses and Gratification, yang memiliki asumsi bahwa kebutuhan akan media dari audiens, maka audiens secara aktf akan mencari dan memilih media sebagai sumber informasi. Pemilihan tersebut menuntut audiensnya untuk selektif dalam memilih media. Selektifitas dalam memilih disebut sebagai preferensi. Audiens tidak lagi pasif menerima stimulus media massa, dan media massa memiliki efek terbatas dalam mempengaruhi audiens termasuk dalam hal penggunaannya.

Sehubungan dengan hal tersebut, peneliti tertarik meneliti audiens media massa sebagai khalayak aktif dalam sudut pandang pendekatan fungsionalis dengan menggunakan teori uses and gratification. 
Menurut McQuail (1997, p.71) dasar teori ini mengemukakan, media dan pilihan terhadap isi media massa mengarah pada tujuan dan kepuasan tertentu. Disini audiens sadar akan kebutuhannya sehubungan dengan media tersebut (motif). Semua faktor yang relevan terhadap formasi audiens seperti motif, kepuasan yang dicari dan didapatkan, pilihan media, serta background variables dapat diukur (McQuail, 1997, p.71). Maka penelitian ini mengukur pilihan media massa untuk mendapatkan gambaran mengenai preferensi siswa SMA di Surabaya dalam menggunakan media massa dalam pencarian informasi studi lanjut perguruan tinggi. (Baran\&Davis, 2010:297).

Nurudin (2010:193) menjelaskan bahwa adanya kebutuhan dan harapan, akan membuat audiens menjadi aktif memilih media yang akan memberikan kepuasan baginya. Hal ini dikarenakan audiens yang aktif perlu memilih media karena masing masing orang berbeda pada tingkat pemanfaatan medianya.Lebit lanjut Frank Biocca involvement (dalam McQuail, 1997:59) menyebutkan konsep audiens aktif yang dimaksdu adalah selektif, yang lainnya yaitu utilitarianism, intentionality, resistance to influence. Hal tersebut diperkuat Severin \& Tankard (2010 : 93) ada 3 jenis selektifitas audiens, yaitu selective exposure, selective attention, dan selective retention).

Preferensi dapat diartikan suatu sifat atau keinginan untuk memilih, teori Uses and Gratfications sebagai landasan untuk melihat kecenderungan dalam memilih media, hal ini dikarenakan audiens akan selektif dalam memilih media untuk memenuhi kebutuhan akan informasi. Preferensi media, dapat diartikan sebagai kecenderungan audience dalam memilih media yang akan digunakan untuk memuaskan informasi yang dibutuhkan.

Lebih lanjut Zizi Papacharissi (2008:

137) mnegemukakan teori Uses and Gratifications melihat perspektif komunikasi secara psikologis bagaimana individu menggunakan media massa. Katz, Jay G. Blumber, dan Michael Gurevitch dalam (Rakhmat, 2008: 205) adalah adanya kebutuhan sosial psikologis dari individu yang menyebabkan munculnya kebutuhan, sehingga menciptakan harapan terhadap media massa. Hal ini membuat adanya perbedaan pola penggunaan media yang akhirnya menghasilkan pemenuhan kebutuhan dan juga akibat lain yang mungkin tidak diharapkan individu. Teori ini menganggap individu sebagai mahluk yang supra-rasional yaitu berpikiran masuk akal sekalipun tidak sesuai dengan hukum alam; serta sangat selektif terhadap media.

Berdasarkan pengamatan peneliti, beragam media promosi Perguruan Tinggi dikemas kreatif dan menarik, dengan menampilkan foto pendukung untuk mempermudah siswa SMA membacanya. Berbagai macam media digunakan Facebook dan Website memiliki yang memuat banyak berita kegiatan kampus, prestasi, foto kegiatan, video dan juga infografis. Banyak pula muncul media pendukung lainnya seperti brosur dan flyer, agar lebih menjangkau sasaran yang tidak terjangkau oleh media besar lainnya.

Peneliti tertarik untuk mengetahui preferensi siswa SMA Surabaya dalam pencarian informasi studi lanjut perguruan tinggi. Fenomena ini muncul karena peneliti mengamati bahwa seluruh media baik saluran formal ataupun informal digunakan untuk sarana promosi kegiatan Surabaya khususnya remaja di usia sekolah menengah 
atas, tentu memiliki kebutuhan akan informasi yang berbeda. Penelitian akan berfokus pada media sumber informasi tentang studi lanjut perguruan tinggi. Metode penelitian yang digunakan adalah metode survei.

\section{Uses and Gratification}

Herbert Blumer dan Elihu Katz pada tahun 1974 memperkenalkan Teori Uses and Gratifications melalui bukunya yang berjudul The Uses Of Mass Communication; Current Perpective On Gratification Receach. Teori ini mengangkat perspektif bahwa motif, perilaku dan sikap berhubungan dengan konsumsi media yang akan mempengaruhi individu (Papacharissi, 2008: 137). Mereka mengemukakan bahwa kajian - kajian tersebut berkaitan dengan:

"(1) asal usul sosial dan psikologis; (2) kebutuhan, yang melahirkan; (3) harapan harapan akan; (4) media massa atau sumber - sumber lain, yang mengarah pada; (5) berbagai pola paparan media yang berbeda (atau ketertarikan dalam berbagai aktivitas lain), yang menghasilkan; (6) gratifikasi kebutuhan maupun; (7) konsekuensi - konsekuennsi lain, mungkin merupakan konsekuensi yang paling tidak diniatkan" (Severin dan Tankard, 2014 : 355).

Kekuatan teori ini ada pada keragaman konteks media yang dapat kita gunakan. Asumsi dalam teori ini mengemukakan

1. Audiens bersikap aktif, artinya daam perannnya untuk memanfaatkan media massa bertujuan pada sasaran.

2. Dalam proses kegiatan komunikasi massa, ada keterkaitan antara kebutuhan dan pilihan media yang menitikberatkan pada audiens.
3. Media juga ada persaingan dengan sumber - sumber pemenuhan kebutuhan yang lain untuk memnuh kebutuhan audinsnya (hal. 22 - 23).

Dengan kata lain, teori ini menyatakan bahwa orang akan secara aktif mencari media dan isi untuk dapat menghasilkan kepuasan tertentu. Istilah khalayak media dapat secara sederhana diartikan sebagai sekumpulan orang yang menjadi pembaca, pendengar, dan pemirsa berbagai media atau komponen isinya (McQuail, 1987: 201). Dalam penelitian tentang media terdapat dua konsep mengenai khlayak, yaitu khalayak aktif dan khalayak pasif. Khalayak yang aktif berarti ia dapat menggunakan media sesuai kebutuhan untuk memenuhi kepuasannya.

\section{Sumber Informasi Pembelian}

Sebelum memutuskan pembelian barang, calon konsumen akan melalui tahapan dalam pembelian. Disebut pencarian sumber informasi Sumber informasi konsumen yang dilakukan oleh calon konsumen oleh Engel digolongkan ke dalam empat kelompok sebagai berikut:

a. Sumber pribadi : sumber ini berasal dari keluarga, teman, tetangga ataupu kenalan, Sumber informasi ini sifatnya akan lebih banyak memberikan penilaian, dan evaluasi serta memperkuat informasi mengenail produk yang diterima calon pembeli.

b. Sumber komersial : sumber informasi ini diperoleh dari berbagai media massa, baik media cetak, elektronik, televisi, radio dan internet. Selain itu juga dapat diperoleh dapat melalui iklan, wiraniaga, penyalur, kemasan, pajangan di toko. sifatnya lebih 
banyak memberitahukan hal-hal seputar produk

c. Sumber publik : sumber informasi ini informasi yang diberikan biasanya melalui demo produk, event maupun testimoni orang-orang terkenal.Kecenderungan publik dalam mengapresiasi suatu produk.

d. Sumber pengalaman $\rightarrow$ berupa pengalaman sebelumnya berkaitan dengan penggunaan produk untuk memenuhi suatu kebutuhan. Setiap sumber informasi melaksanakan fungsi yang berbeda dalam mempengaruhi keputusan pembelian. Sumber komersial biasanya melaksanakan fungsi informasi, sementara sumber pribadi melaksanakan fungsi legitimasi atau evaluasi.

James Engel (1995) mencoba mengklasifikasikan sumber informasi kedalam jenisnya yitu sumber informasi komersial, non-komersial, personal, dan impersonal. Berbagai sumber informasi tersebut dijelaskan dalam table sebagai berikut :

Tabel 1. Sumber informasi konsumen

\begin{tabular}{|c|c|c|}
\hline & Impersonal & Personal \\
\hline Komersial & $\begin{array}{l}\text { - } \text { Iklan } \\
\text { - Informasi di } \\
\text { dalam toko } \\
\text { atau gerai }\end{array}$ & $\begin{array}{ll} & \text { Wiraniaga } \\
- & \text { Sales } \\
& \text { Promotio } \\
& n \\
\end{array}$ \\
\hline $\begin{array}{l}\text { Non } \\
\text { komersial }\end{array}$ & $\begin{array}{ll}- & \text { Media umum } \\
\text { - } & \text { Eksperimenta } \\
& 1 \\
\end{array}$ & $\begin{array}{ll}\text { - } & \text { Orang lain } \\
\text { - } & \text { Kolega } \\
\text { - } & \text { Saudara } \\
\end{array}$ \\
\hline
\end{tabular}

Sumber: James F. Engel, 1995

\section{Preferensi Media}

Pada teori Uses and Gratifications, audiens bersikap aktif yang berarti ada peranan penting dalam penggunaan media massa. Proses memilih media dilakukan dengan selektif. Jadi, dari berbagai sumber bacaan peneliti menyimpulkan, bahwa revelansi teori $U$ \& $G$ dengan preferensi adalah audiens yang aktif berarti selektif dalam memilih media.

Berdasarkan pengertian dari Kamus Besar Bahasa Indonesia (KBBI) versi online diakses pada 15 Oktober 2017, preferensi berarti (1) (hak untuk) didahulukan dan diutamakan daripada yang lain; prioritas; (2) pilihan; kecenderungan; kesukaan. Preferensi media berarti pemilihan dari sekian banyak media yang berlomba untuk memberi kepuasan kepada audiens. Dalam melakukan preferensi terdapat sikap selektif.

Selektifitas memiliki 3 bentuk proses, diantaranya selective exposure, selective attention, dan selective retention (Severin dan Tankard, 2014: 92-93). Selective exposure adalah merupakan kecenderungan seseorang untuk memastikan dirinya pada suatu komunikasi yang sesuai dengan sikap-sikap mereka yang ada dan untuk menghindari komunikasi yang tidak sesuai. Selective attention adalah kecenderungan seseorang untuk memerhatikan bagian-bagian dari sebuah pesan yang sama dengan sikap, kepercayaan, atau tingkah laku yang dipegang dengan kuat oleh dirinya. Selective retention adalah kecenderungan seseorang untuk mengingat kembali suatu informasi yang dipengaruhi oleh keinginan, kebutuhan, sikap dan faktor-faktor psikologis lain.

Proses selektif dapat juga disebut sebagai empat lingkaran pertahanan, yaitu selective exposure sebagai lingkaran yang paling besar, kemudian selective attention, selective perception, dan selective retention. Informasi yang tidak penting kadangkadang menjadi bagian utama pada lingkaran yang paling jauh (Severin dan 
Tankard, 2005: 93). Jika seseorang menginginkan suatu informasi yang beragam dalam sebuah pesan, maka ia dapat menggunakan pemilihan selective attention pada bagian pesan-pesan yang dapat diterima. Jika dia tidak berhasil mendapatkan suatu informasi, maka ia dapat menggunakan selective perception saat mengembalikan pesan. Jika gagal lagi, ia dapat menggunakan selective retention dengan cara melupakan informasi yang berbeda.

.Penelitian ini akan melihat konsumen sebagai audience aktif dalam mencari informasi melalui media, sehingga melihat terkait audience researchnya. Adapun data yang dicari melalui audience research dikelompokkan dalam audience profile, media exposure, audience rating, dan efek komunikasi bermedia. Namun dalam penelitian ini, penulis tidak akan menggunakan efek komunikasi bermedia.

Data mengenai audience profile mencakup variabel - variabel :

1. Sex (Jenis Kelamin),

2. Age (Umur),

3. Education Level (Tingkat Pendidikan),

4. Income (Pendapatan),

5. Occupation (Kedudukan/Jabatan), dsb.

6. Pemilikan Media (Media Ownership)

Audience rating adalah perankingan yang dilakukan audience digunakan untuk mengetahui persepsi audience terhadap jenis media, jenis informasi, format acara, dan komunikator yang menjadi favorit audience (Sari, 1993:29). Audience rating sangat baik dilakukan untuk mencari informasi yang paling dibutuhkan audience, media yang sering digunakan audience, format acara yang paling disenangi audience, dan komunikator (broadcaster, newscaster, reporter, dan lain - lainnya) yang paling bagus dalam menyampaikan pesan - pesan komunikasi massa.

\section{Metodologi Penelitian}

Pendekatan penelitian ini kuantitatif dengan menggunakan kuesioner sebagai metode pengumpulan datanya. Jenis penelitian ini menggunakan penelitan deskriptif,. Metode penelitian yang digunakan peneliti adalah metode penelitian survey. Variabel penelitian yang digunakan adalah preferensi siswa SMA Surabaya dalam pencarian informasi studi lanjut perguruan tinggi. Dalam penelitian ini digunakan variabel tunggal. Variabel ini akan diteliti menggunakan metode audience research yang menggunakan indikator audience profile, media exposure dan audience rating.

Populasi dalam penelitian ini adalah siswa SMA di Surabaya sebanyak 115.043 berdasarkan data Badan Pusat Statistik Kota Surabaya tahun 2016 untuk kategori usia 1518 tahun.. Dan sampel penelitian adalah 100 siswa SMA. Teknik penarikan sampel yang digunakan dalam penelitian ini adalah probability sampling, yaitu simple random sampling, setiap anggota populasi dianggap mempunyai kesempatan yang sama sebagai sampel. Dalam menentukan sampel dilakukan pengundian sekolah sesuai wilayah dis. Surabaya terbagi menjadi 5 wilayah, yaitu Surabaya Utara, Surabaya Selatan, Surabaya Barat, Surabaya Timur, dan Surabaya Pusat 


\section{Hasil dan Pembahasan}

Identitas responden penelitian dibawah ini merupakan siswa berusia 15-19 tahun yang sedang menempuh pendidikan di Sekolah Menengah Atas di Surabaya

Tabel 2. Identitas Responden berdasarkan Jenis Kelamin $(n=100)$

\begin{tabular}{|l|l|l|l|}
\hline No. & Jenis Kelamin & Frekuensi & Percent \\
\hline 1. & Laki-laki & 49 & $49 \%$ \\
\hline 2. & Perempuan & 51 & $51 \%$ \\
\hline \multicolumn{2}{|l|}{ TOTAL } & $\mathbf{1 0 0}$ & $\mathbf{1 0 0 \%}$ \\
\hline
\end{tabular}

Sumber : Kuesioner no. 2

Dari paparan tabel 2. dapat dilihat bahwa jumlah perempuan yang melakukan pencarian informasi studi lanjut dari media publikasi milik Perguruan Tinggi lebih banyak dibandingkan dengan laki-laki. Perempuan yang mengisi kuesioner terdapat sebanyak 51 orang (51\%) dan Laki-laki 49 orang (49\%)., Dari paparan tabel 3. dapat dilihat bahwa siswa SMA yang melakukan pencarian informasi studi lanjut dari media publikasi milik Perguruan Tinggi didominasi oleh siswa yang sedang menempuh studi kelas 3 sebanyak 77 orang (77\%), sedangkan siswa yang menempuh studi kelas 2 melakukan pencarian informasi studi lanjut dari media publikasi milik Perguruan Tinggi sebanyak 23 orang (23\%)

Tabel 3. Identitas Responden berdasarkan Menempuh Studi Kelas $(\mathrm{n}=100)$

\begin{tabular}{|l|l|l|l|}
\hline No. & Studi Kelas & Frekuensi & Percent \\
\hline 1. & 2 (Dua) & 23 & $23 \%$ \\
\hline 2. & 3 (Tiga) & 77 & $77 \%$ \\
\hline \multicolumn{2}{|l|}{ Total } & $\mathbf{1 0 0}$ & $\mathbf{1 0 0 \%}$ \\
\hline
\end{tabular}

Sumber : Kuesioner no. 2

\section{Deskripsi Jenis Informasi dari Sumber Informasi Personal}

Dibawah ini adalah pemaparan hasil pembacaan tabel terkait jenis informasi yang dicari dari sumber informasi personal. Pada sub bab ini, sumber informasi personal dibagi menjadi 3 sumber yaitu guru Bimbingan Konseling (BK), orangtua dan kakak kelas/saudara.

Table 4. Jenis Informasi dari Sumber Informasi Personal

\begin{tabular}{|l|c|c|c|}
\hline \multicolumn{1}{|c|}{ Jenis Informasi } & Guru BK & Orang Tua & Kakak \\
\cline { 2 - 4 } & Frekuensi & Frekuensi & Frekuensi \\
\hline $\begin{array}{l}\text { Menentukan Jurusan yang sesuai dengan } \\
\text { diri saya }\end{array}$ & 62 & 28 & 23 \\
\hline Universitas yang sesuai dengan diri saya & 2 & 65 & \\
\hline $\begin{array}{l}\text { Prospek kerja dari jurusan yang akan saya } \\
\text { pilih }\end{array}$ & 9 & 5 & 28 \\
\hline Kesulitan Kuliah & 26 & 1 & 49 \\
\hline Syarat untuk mendaftar kuliah & 1 & 1 & $\mathbf{1 0 0}$ \\
\hline Total & $\mathbf{1 0 0}$ & $\mathbf{1 0 0}$ & \\
\hline
\end{tabular}


Dari paparan tabel 4. dapat dilihat bahwa jenis informasi yang dicari dari sumber informasi personal guru BK paling tinggi adalah terkait menentukan jurusan yang sesuai dengan diri siswa, yaitu sebanyak 62 orang (62\%), sedangkan yang paling rendah adalah informasi terkait universitas yang sesuai dengan diri mereka sebesar 2 orang (2\%). Selain itu dari paparan tabel tersebut apat dilihat bahwa jenis informasi yang dicari dari sumber informasi personal orangtua paling tinggi adalah terkait universitas yang sesuai dengan diri mereka sebanyak 65 orang (65\%), sedangkan yang paling rendah adalah informasi terkait prospek kerja dari jurusan yang akan mereka pilih sebanyak 1 orang $(1 \%)$..

Sumber informasi personal kakak kelas/saudara paling tinggi adalah terkait kesulitan kuliah sebanyak 49 orang (49\%), sedangkan yang paling rendah adalah informasi terkait jurusan yang sesuai dengan diri mereka dipilih sebanyak 23 orang (23\%).
Dari jenis informasi dan sumber informasi siswa SMA, dapat dilihat bahwa terkait topik kesesuaia jurusan yang akan dipilih Guru Bimbingan Konseling menjadi sumber informasi utama siswa SMA. Namun untuk penentuan Universitas mana yang akan dipilih, siswa SMA cenderung mencari informasi kepada orang tua

\section{Deskripsi Media Exposure}

Berikut ini adalah hasil paparan data pada kategori media exposure yang menjelaskan tentang paparan informasi dari media publikasi yang diterima oleh responden dan perilaku responden terhadap media publikasi terkait studi lanjut pada perguruan tinggi.

\section{Deskripsi Hasil Preferensi Media Publikasi}

Dalam sub bab media exposure responden diminta mengurutkan media yang paling sering mereka gunakan dalam pencarian informasi studi lanjut perguruan tinggi. Hasil preferensi responden dijabarkan dalam tabel dibawah ini :

Tabel 5. Preferensi Media Publikasi $(n=100)$

\begin{tabular}{|c|c|c|c|c|c|c|c|c|c|}
\hline \multirow[t]{2}{*}{ No. } & \multirow[t]{2}{*}{$\begin{array}{c}\text { Media } \\
\text { Publikasi }\end{array}$} & \multicolumn{2}{|c|}{$\begin{array}{c}\text { Media } \\
\text { Komunikasi } \\
\text { Pilihan } 1\end{array}$} & \multicolumn{2}{|c|}{$\begin{array}{c}\text { Media } \\
\text { Komunikasi } \\
\text { Pilihan } 2\end{array}$} & \multicolumn{2}{|c|}{$\begin{array}{c}\text { Media } \\
\text { Komunikasi } \\
\text { Pilihan } 3\end{array}$} & \multicolumn{2}{|c|}{$\begin{array}{c}\text { Media } \\
\text { Komunikasi } \\
\text { Pilihan } 4\end{array}$} \\
\hline & & $\mathbf{F}$ & $\%$ & $\mathbf{F}$ & $\%$ & $\mathbf{F}$ & $\%$ & $\mathbf{F}$ & $\%$ \\
\hline 1. & Majalah & 0 & 0 & 1 & $1 \%$ & 36 & $36 \%$ & 63 & $63 \%$ \\
\hline 2. & Facebook & 34 & $34 \%$ & 47 & $47 \%$ & 19 & $19 \%$ & 0 & $0 \%$ \\
\hline 3. & Instagram & 54 & $54 \%$ & 39 & $39 \%$ & 7 & $7 \%$ & 0 & $0 \%$ \\
\hline 4. & Website & 12 & $12 \%$ & 13 & $13 \%$ & 38 & $38 \%$ & 37 & $37 \%$ \\
\hline & OTAL & 100 & $100 \%$ & 100 & $100 \%$ & 100 & $100 \%$ & 100 & $100 \%$ \\
\hline
\end{tabular}

Sumber : Kuesioner P4 
Dari paparan tabel 5. dapat dilihat bahwa dari total 100 responden yang melakukan pencarian informasi, mereka melakukan pencarian informasi pada media publikasi yang berbeda-beda. Terlihat pada preferensi pilihan pertama pada kategori pilihan 1, media publikasi yang paling banyak digunakan adalah Instagram yang dimiliki oleh masing-masing perguruan tinggi dengan jumlah responden sebanyak 54 orang (54\%). Berikutnya, pada preferensi pilihan pertama pada kategori pilihan yang kedua, media publikasi yang paling banyak digunakan adalah facebook yang dimiliki dan dikelola oleh masing-masing perguruan tinggi sebanyak 47 orang (47\%).Selanjutnya, pada preferensi pilihan ketiga, media publikasi yang paling banyak digunakan pada kategori pilihan ketiga adalah website yang dilimili oleh masing-masing perguruan tinggi yaitu sebanyak 38 orang (38\%). Selanjutnya, pada kategori pilihan keempat, media publikasi yang paling banyak diakses pada kategori ini adalah majalah yang diterbitkan oleh masing-masing perguruan tinggi yaitu sebanyak 63 orang (63\%).

\section{Deskripsi Alasan Pemilihan Media Publikasi}

Seteleh memilih media publikasi yang digunakan sebagai pemenuhan informasi oleh responden, peneliti ingin mengetahui apa saja alasan mereka memilih media publikasi tersebut. Hasil dari kuesioner yang telah diisi oleh responden akan dipaparkan dalam tabel dibawah ini :

Dari paparan tabel 6. dapat dilihat bahwa alasan responden memilih media publikasi tersebut karena mudah diakses dengan total responden yang memilih sebanyak 41 orang (41\%) dan media publikasi tersebut paling update informasinya dipilih sebanyak 32 orang $(32 \%)$.

Tabel 6. Alasan Memilih Media Publikasi

$$
(n=100)
$$

\begin{tabular}{|c|l|c|c|}
\hline No. & \multicolumn{1}{|c|}{$\begin{array}{c}\text { Alasan } \\
\text { Memilih }\end{array}$} & Frekuensi & Percent \\
\hline 1. & $\begin{array}{l}\text { Mudah } \\
\text { diakses }\end{array}$ & 41 & $41 \%$ \\
\hline 2. & $\begin{array}{l}\text { Kontennya } \\
\text { menarik }\end{array}$ & 3 & $8 \%$ \\
\hline 3. & $\begin{array}{l}\text { Mudah } \\
\text { dimengerti }\end{array}$ & 8 & $32 \%$ \\
\hline 4. & Paling update & 32 & $16 \%$ \\
\hline 5. & $\begin{array}{l}\text { Informasi } \\
\text { lengkap }\end{array}$ & 100 & $100 \%$ \\
\hline \multicolumn{2}{|l|}{ Total }
\end{tabular}

Sumber : Pernyataan Kuesioner P5

\section{Deskripsi Durasi Akses Media Publikasi}

Penelitian ini juga menguraikan terkait lama responden mengakses media publikasi tersebut saat melakukan pencarian informasi. Hasil dari kuesioner yang telah diisi oleh responden diuraikan pada tabel dibawah ini :

Tabel 7. Durasi Akses Media Publikasi

$$
(n=100)
$$

\begin{tabular}{|c|l|c|c|}
\hline No. & Durasi & Frekuensi & Percent \\
\hline 1. & $<2$ jam & 70 & $70 \%$ \\
\hline 2. & $2-4 \mathrm{jam}$ & 11 & $11 \%$ \\
\hline 3. & $>4 \mathrm{jam}$ & 19 & $19 \%$ \\
\hline \multicolumn{2}{|l|}{ Total } & $\mathbf{1 0 0}$ & $\mathbf{1 0 0 \%}$ \\
\hline
\end{tabular}

Sumber : Pernyataan Kuesioner P6 
Dari paparan tabel 7 dapat dilihat bahwa durasi atau lama responden dalam mengakses media publikasi terkait informasi studi lanjut perguruan tinggi selama kurang dari 2 jam $(<2$ jam $)$ dipilih sebanyak 70 orang $(70 \%)$

\section{Deskripsi Frekuensi Akses Media Publikasi}

Hal berikutnya yang juga dijelaskan dalam penelitian ini terkait frekuensi responden mengakses media publikasi perguruan tinggi. Data yang didapatkan akan dijabarkan pada tabel berikut :

Tabel 8. Frekuensi Akses Media Publikasi $(n=100)$

\begin{tabular}{|c|l|r|r|}
\hline No. & Frekuensi & Frekuensi & Percent \\
\hline 1. & $\begin{array}{l}\text { Seminggu } \\
\text { sekali }\end{array}$ & 51 & $51 \%$ \\
\hline 2. & $\begin{array}{l}\text { Tiga kali } \\
\text { seminggu }\end{array}$ & 16 & $16 \%$ \\
\hline 3. & Setiap hari & 33 & $33 \%$ \\
\hline \multicolumn{2}{|c|}{ Total } & $\mathbf{1 0 0}$ & $\mathbf{1 0 0 \%}$ \\
\hline
\end{tabular}

Sumber : Pernyataan Kuesioner P7

Dari paparan tabel 8 dapat dilihat bahwa frekuensi responden mengakses media publikasi milik perguruan tinggi adalah seminggu sekali, dengan total responden yang memilih sebanyak 51 orang $(51 \%)$

\section{Deskripsi Audience Rating}

Pada sub bab ini akan dijelaskan secara rinci hasil dari responden berdasarkan media publikasi perguruan tinggi yang telah responden ikuti. Sub bab audience rating ini hanya akan dibahas secara spesifik tiga jenis media publikasi yang menjadi preferensi utama saja.

\section{Deskripsi Audience Rating Instagram}

Pada bahasan sub bab ini, peneliti akan menjelaskan hasil yang didapatkan dari responden mengenai audience rating yang akan terbagi dalam 4 media publikasi, yaitu majalah, facebook, Instagram dan website. Berikut pemaparan data yang didapatkan :

\section{Deskripsi Fitur yang Disukai di Instagram}

Majalah sebagai media informasi memiliki beberapa rubric yang dapat membagi jenis informasi yang hendak dibagikan kepada pembacanya. Berikut hasil kuesioner yang didapat dari responden mengenai media publikasi majalah :

Tabel 9. Fitur yang disukai di Instagram

$$
(n=100)
$$

\begin{tabular}{|c|l|c|c|}
\hline No. & \multicolumn{1}{|c|}{ Fitur } & Frekuensi & Percent \\
\hline 1. & Comment & 3 & $3 \%$ \\
\hline 2. & $\begin{array}{l}\text { Instagram } \\
\text { Story }\end{array}$ & 55 & $55 \%$ \\
\hline 3. & Saved & 15 & $15 \%$ \\
\hline 4. & Lainnya & 27 & $27 \%$ \\
\hline \multicolumn{2}{|l|}{ Total } & $\mathbf{1 0 0}$ & $\mathbf{1 0 0 \%}$ \\
\hline
\end{tabular}

Sumber : Pernyataan Kuesioner P15

Dari paparan tabel 9 dapat dilihat bahwa fitur yang disukai oleh responden saat mereka mengakses media publikasi Instagram milik masing-masing perguruan tinggi ialah Instagram story dengan perolehan frekuensi sebanyak 55 responden $(55 \%)$

\section{Deskripsi Jenis Publikasi yang Disukai saat Mengakses Instagram}

Jenis publikasi yang disampaikan oleh masing-masing Instagram milik 
perguruan tinggi pasti berbeda-beda. Pada sub bab ini, peneliti mencoba mendapatkan hasil tentang jenis publikasi yang disukai oleh responden saat mereka membuka Instagram masing-masing perguruan tinggi. Hasil tersebut akan ditampilkan pada tabel data sebagai berikut :

Tabel 10. Jenis Publikasi yang Disukai

$$
(\mathrm{n}=100)
$$

\begin{tabular}{|c|c|c|c|}
\hline No. & $\begin{array}{c}\text { Jenis } \\
\text { Publikasi }\end{array}$ & Frekuensi & Percent \\
\hline 1. & Foto & 2 & $2 \%$ \\
\hline 2. & Video & 33 & $33 \%$ \\
\hline 3. & $\begin{array}{c}\text { Berita dan } \\
\text { foto }\end{array}$ & 40 & $40 \%$ \\
\hline 4. & $\begin{array}{c}\text { Berita dan } \\
\text { video }\end{array}$ & 11 & $11 \%$ \\
\hline 5. & \begin{tabular}{c} 
Infografis \\
\multicolumn{2}{|c|}{ Total }
\end{tabular} & $\mathbf{1 0 0}$ & $\mathbf{1 0 0 \%}$ \\
\hline
\end{tabular}

Sumber : Pernyataan Kuesioner P16

Dari paparan tabel 10 ditemukan bahwa jenis publikasi yang disukai oleh responden saat mengakses akun Instagram milik masing-masing perguruan tinggi adalah jenis informasi dengan bentuk berita dan foto. Jenis publikasi berita dan foto dipilih oleh 40 responden (40\%), sedangkan untuk jenis publikasi dengan bentuk informasi berupa video dipilih oleh 33 repsonden $(33 \%)$.

\section{Deskripsi Alasan Menyukai Jenis Publikasi di Instagram}

Setelah sub bab sebelumnya mendapatkan hasil tentang jenis informasi yang dipublikasikan, selanjutnya peneliti mencoba untuk menguraikan alasan responden menyukai jenis informasi publikasi tersebut. Masing-masing responden tentunya memiliki alasan yang berbeda-beda mengapa mereka memilih jenis informasi publikasi tertetu. Tabel berikut akan menampilkan data alasanalasan yang mendasari responden memilik jenis informasi tersebut :

Tabel 11. Alasan Menyukai Jenis Publikasi $(n=100)$

\begin{tabular}{|c|l|r|r|}
\hline No. & $\begin{array}{c}\text { Alasan } \\
\text { Menyukai }\end{array}$ & Frekuensi & Percent \\
\hline 1. & Menarik & 74 & $74 \%$ \\
\hline 2. & Penting & 26 & $26 \%$ \\
\hline \multicolumn{2}{|c|}{ Total } & 100 & $100 \%$ \\
\hline
\end{tabular}

Sumber : Pernyataan Kuesioner P17

Dari paparan table 11 dapat dikatakan bahwa alasan responden menyukai jenis publikasi di Instagram karena jenis informasi yang dipublikasi oleh media social Instagram karena menarik. Alasan ini paling banyak dipilih oleh 74 responden $(74 \%)$ apabila dibandingkan dengan alasan penting yang hanya dipilih oleh 26 orang $(26 \%)$.

\section{Deskripsi Jenis Informasi yang dicari di akun Instagram}

Pihak perguruan tinggi mungkin saja tidak menampilkan informasi sesuai dengan kebutuhan audience-nya. Dalam sub bab ini, peneliti mencoba untuk menguraikan jenis informasi apa yang menjadi kebutuhan responden saat mengakses media social Instagram milik perguruan tinggi. Tabel berikut akan menampilkan data jenis informasi yang dicari oleh responden ketik amengakses Instagram milik perguruan tinggi : 
Tabel 12. Jenis Informasi yang dicari

Responden $(n=100)$

\begin{tabular}{|c|l|r|r|}
\hline $\begin{array}{c}\text { N } \\
\text { o. }\end{array}$ & $\begin{array}{l}\text { Jenis Informasi } \\
\text { yang dicari }\end{array}$ & $\begin{array}{c}\text { Frekue } \\
\text { nsi }\end{array}$ & $\begin{array}{c}\text { Pere } \\
\text { nt }\end{array}$ \\
\hline 1. & Pilihan jurusan & 46 & $46 \%$ \\
\hline 2. & Biaya kuliah & 1 & $1 \%$ \\
\hline 3. & $\begin{array}{l}\text { Prestasi } \\
\text { perguruan } \\
\text { tinggi } \\
\text { bersangkutan/ju } \\
\text { rusan }\end{array}$ & 28 & $28 \%$ \\
\hline 4. & Testimoni & $\mathbf{1 0 0}$ & $\mathbf{1 0 0}$ \\
\hline \multicolumn{2}{|l|}{ Total } & $25 \%$ \\
\hline
\end{tabular}

Sumber : Pernyataan Kuesioner P18

Dari paparan tabel 12 didapatkan hasil bahwa jenis informasi yang paling banyak dicari oleh responden adalah jenis informasi terkait pilihan jurusan yang ditawarkan oleh masing-masing Perguruan Tinggi. Jenis informasi terkait pilihan jurusan tersebut dipilih oleh sebanyak 46 orang responden $(46 \%)$.

Setelah itu, pada posisi selanjutnya jenis informasi yang paling banyak diakses oleh resonden adalah terkait prestasi Perguruan Tinggi yang bersangkutan. Jenis informasi ini dipilih oleh total 28 orang responden $(28 \%)$

\section{Deskripsi Waktu Mengakses Instagram}

Hasil dari jawaban responden untuk mengetahui waktu yang sering digunakan untuk mengakses Instagram masing-masing Perguruan Tinggi dijelaskan di tabel berikut :
Tabel I3. Waktu yang Digunakan untuk Mengakses $(\mathrm{n}=100)$

\begin{tabular}{|c|c|r|r|}
\hline No. & $\begin{array}{l}\text { Waktu yang } \\
\text { Digunakan }\end{array}$ & Frekuensi & Perent \\
\hline 1. & $11.00-17.00$ & 5 & $5 \%$ \\
\hline 2. & $17.00-21.00$ & 95 & $95 \%$ \\
\hline \multicolumn{2}{|c|}{ Total } & 100 & $100 \%$ \\
\hline
\end{tabular}

Sumber : Pernyataan Kuesioner P19

Dari paparan tabel 13 didapatkan hasil bahwa waktu yang digunakan untuk mengakses informasi terkait studi lanjut Perguruan Tinggi adalah sore menjelang malam hari yaitu pukul $17.00-21.00$ yang dipilih sebanyak 95 responden (95\%).

\section{Deskripsi Audience Rating Facebook}

Sub bab ini peneliti mencoba untuk mendeskripsikan hasil jawaban terponden terkait audience rating untuk media social facebook masing-masing Perguruan Tinggi.

\section{Deskripsi Jenis Publikasi yang Disukai saat Mengakses Facebook}

Facebook termasuk salah satu media sosial yang paling banyak diakses oleh remaja dan facebook tentunya memiliki beberapa fitur-fitur unggulan. Fitur-fitur yang dapat dimanfaatkan oleh akun pengikutnya guna memenuhi berbagai kebutuhan informasi mereka terkait sebuah informasi. Berikut hasil jawaban responden terhadap fitur Facebook yang disukai : 
Tabel 14. Jenis Publikasi yang disukai saat

Mengakses Facebook $(\mathrm{n}=100)$

\begin{tabular}{|c|l|r|r|}
\hline No. & $\begin{array}{c}\text { Jenis } \\
\text { Publikasi }\end{array}$ & Frekuensi & Percent \\
\hline 1. & Foto & 21 & $21 \%$ \\
\hline 2. & Video & 1 & $1 \%$ \\
\hline 3. & $\begin{array}{l}\text { Berita dan } \\
\text { foto }\end{array}$ & 72 & $72 \%$ \\
\hline 4. & $\begin{array}{l}\text { Berita dan } \\
\text { video }\end{array}$ & 5 & $1 \%$ \\
\hline 5. & Infografis & 100 & $100 \%$ \\
\hline \multicolumn{2}{|l|}{ Total }
\end{tabular}

Sumber : Pernyataan Kuesioner P11

Dari paparan tabel 14 didapatkan hasil bahwa jenis publikasi yang disukai oleh responden ketika mereka mengakses informasi terkait studi lanjut Perguruan Tinggi melalui facebook adalah jenis publikasi berupa berita dan foto. Jenis publikasi berupa berita dan foto tersebut dipilih oleh responden sebanyak 72 orang responden $(72 \%)$.

\section{Deskripsi Alasan Menyukai Jenis Publikasi di Facebook}

Setelah mengetahui jenis publikasi yang disukai oleh responden ketika mereka mengakses informasi terkait studi lanjut Perguruan Tinggi, peneliti mencoba mencari tahu alasan yang mendasari responden menyukai jenis publikasi tersebut. Hasil dari jawaban responden dipaparkan dalam tabel sebagai berikut :
Tabel 15. Alasan Menyukasi Jenis

Publikasi $(\mathrm{n}=100)$

\begin{tabular}{|c|c|c|c|}
\hline No. & $\begin{array}{c}\text { Alasan } \\
\text { Menyukasi } \\
\text { Jenis } \\
\text { Publikasi }\end{array}$ & Frekuensi & Percent \\
\hline 1. & Menarik & 45 & $45 \%$ \\
\hline 2. & Penting & 55 & $55 \%$ \\
\hline \multicolumn{2}{|c|}{ Total } & 100 & $100 \%$ \\
\hline
\end{tabular}

hasil bahwa alasan responden menyukai jenis publikasi berita dan foto karena jenis publikasi berita dan foto tersebut dirasa penting untuk mereka ketahui dan pada akhirnya memilih jurusan yang diinginkan oleh responden. Alasan menyukai jenis publikasi karena hal yang penting tersebut dipilih oleh sebanyak 55 orang responden $(55 \%)$

Sedangkan alasan menyukai jenis publikasi yang berikutnya paling banyak dipilih oleh responden adalah karena jenis publikasi berita dan fiti dianggap menarik untuk mereka baca dan lihat. Alasan tersebut dipilih oleh sebanyak 45 orang responden $(45 \%)$

\section{Deskripsi Jenis Informasi yang dicari di Facebook}

Jenis informasi yang disajikan oleh masing-masing Perguruan Tinggi tidak selalu sesuai dengan yang diinginkan oleh masyarakat Surabaya. Sehingga, peneliti ingin mengetahui jenis informasi yang dicari oleh responden remaja. Hasil dari kuesioner yang telah diisi responden dijabarkan dalam tabel berikut : 
Tabel 16. Jenis Informasi yang dicari di Facebook $(\mathrm{n}=100)$

\begin{tabular}{|l|l|r|r|}
\hline $\begin{array}{c}\text { N } \\
\text { o. }\end{array}$ & $\begin{array}{l}\text { Jenis Informasi } \\
\text { yang dicari }\end{array}$ & $\begin{array}{c}\text { Frekue } \\
\text { nsi }\end{array}$ & $\begin{array}{c}\text { Perce } \\
\text { nt }\end{array}$ \\
\hline 1. & Pilihan jurusan & 71 & $71 \%$ \\
\hline 2. & Biaya kuliah & 9 & $9 \%$ \\
\hline 3. & $\begin{array}{l}\text { Prestasi } \\
\text { perguruan } \\
\text { tinggi } \\
\text { bersangkutan/ju } \\
\text { rusan }\end{array}$ & 14 & $14 \%$ \\
\hline 4. & Testimoni & 6 & $6 \%$ \\
\hline \multicolumn{2}{|l|}{ Total } & 100 \\
\hline
\end{tabular}

Sumber : Pernyataan Kuesioner P13

Dari paparan tabel 16 didapatkan hasil bahwa jenis informasi yang dicari di facebook adalah terkait pilihan jurusan yang dipilih sebanyak 71 responden (71\%). Banyak akun Perguruan Tinggi yang memang memuat terkait pilihan jurusan yang dimiliki oleh masing-masing Perguruan Tinggi, sehingga menjadi sangat wajar akses informasi yang dicari memang terkait pilihan jurusan.

\section{Deskripsi Waktu Mengakses Facebook}

Responden memiliki waktu tersendiri untuk mengakses Facebook masing-masing Perguruan Tinggi sesuai dengan kegiatan mereka masing-masing. Waktu mengakses tersebut pun cenderung beragam, disini peneliti mencoba menghasilkan jawaban dengan mengelompokkan waktu mengakses menjadi 2 bagian. Tabel berikut menunjukkan hasil jawaban responden terhadap waktu mengakses :
Tabel 17. Waktu Mengakses Facebook

$$
(n=100)
$$

\begin{tabular}{|c|l|r|r|}
\hline No. & $\begin{array}{c}\text { Waktu } \\
\text { Mengakses }\end{array}$ & Frekuensi & Percent \\
\hline 1. & $\begin{array}{l}11.00- \\
17.00\end{array}$ & 5 & $5 \%$ \\
\hline 2. & $\begin{array}{l}17.00- \\
21.00\end{array}$ & 95 & $95 \%$ \\
\hline \multicolumn{2}{|l|}{ Total } & 100 & $100 \%$ \\
\hline
\end{tabular}

Sumber : Pernyataan Kuesioner P14

Dari paparan tabel 17 didapatkan hasil bahwa waktu yang digunakan responden untuk mengakses facebook masing-masing Perguruan Tinggi adalah pukul 17.00 - 21.00 yang dipilih oleh 95 orang responden $(95 \%)$. Waktu sore menjelang malam hari lebih digunakan untuk mengakses media sosial karena pada saat itu mayoritas masyarakat telah menyelesaikan kesibukannya pada hari itu.

\section{Kesimpulan}

Dari hasil pemaparan terkait Preferensi Siswa SMA Surabaya dalam Pencarian Informasi Studi Lanjut Perguruan Tinggi.Pada pencarian informasi menggunakan sumber personal, bahwa terkait topik kesesuaia njurusan yang akan dipilih Guru Bimbingan Konseling menjadi sumber informasi utama siswa SMA. Namun untuk penentuan Universitas mana yang akan dipilih, siswa SMA cenderung mencari informasi kepada orang tua.

Pencarian informasi pada media publikasi yang berbeda-beda. Terlihat pada preferensi pilihan pertama pada kategori pilihan 1, media publikasi yang paling banyak digunakan adalah Instagram yang 
dimiliki oleh masing-masing perguruan tinggi dengan Berikutnya, pada pada kategori pilihan yang kedua, media publikasi yang paling banyak digunakan adalah facebook yang dimiliki dan dikelola oleh masing-masing perguruan tinggi.

\section{Kesimpulan}

Dari hasil penelitian tersebut dapat disarankan bahwa bagi perguruan tinggi dapat semakin meningkatkan kegiatan promosi dengan membuat konten creative pada instagram sehingga memudahkan siswa SMA untuk mencari informasi dan merasa tertarik dengan kegiatan Universitas dan memaksimalkan peran guru BK untuk kegiatan komunikasi pemasaran, serta melakukan kegiatan promosi yang melibatkan orang tua

\section{Daftar Pustaka}

Cutlip, Scott M., Allen H Center, dan Glen M. Broom. 2009. Effective Public Relations. Edisi Kesembilan. Terjemahan. Jakarta:Kencana

Danandjaja. 2012. Metode Penelitian Sosial. Yogyakarta. Graha Ilmu

Hidayat, Dasrun. 2014. Media Public Relations.Yogyakarta: Graha Ilmu

Kriyantono, Rachmat. 2014. Teknik Praktis

Riset Komunikasi; Disertai Contoh Praktis Riset Media, Public Relations, Advertising, Komunikasi Organisasi, Komunikasi Pemasaran. Jakarta: Kencana Prenadamedia Group McQuail, Dennis. 1997. Audience Analysis. California:Sage Publications
Nurudin, M.Si. 2010. Pengantar Komunikasi Massa. Jakarta . Raja Grafindo Persada

Singarimbun, Masri dan Sofian Effendi, 1989. Metode Penelitian Survai. LP3ES, Jakarta.

Tankard, James dan Severin Werner. 2010. Teori Komunikasi, Jakarta: Prenada Media Grup.

Vivian, John. 2010. Teori Komunikasi Edisi kedelapan, Jakarta: Prenanda Media Grup. 